\title{
Application of composite index for sustainability assessment
}

\author{
Renata Dagiliūtè, Sandra Elijošienè \\ Department of Environmental Sciences, Vytautas Magnus University, Vileikos 8, LT-44404, Kaunas, Lithuania
}

\begin{abstract}
Sustainable development more than for twenty years is on local, national and international agenda. Aside political aims and declarations, it is important to assess present situation, compare past and foresee future trends. As sustainable development is multidimensional and covers various aspects of life, need to take both quantitative and qualitative indicators into account challenges sustainability assessment in general. Therefore, this paper aims to evaluate the alteration of sustainable development by applying composite index for Lithuania and other EU countries during 2004-2010. To achieve this goal, changes in the main economic, environmental and social indicators of EU15, Baltic States, Poland and Czech Republic have been analysed. OECD methodology (2008) was used to construct and calculate integrated sustainability index of selected countries. Analysis reveal that indicators like GDP, export, energy and material intensity, children mortality, poverty etc. have improved in countries which recently have joined EU. Economy sub-index was the highest in ES15 and environmental index - in Lithuania and Latvia. Meanwhile, overall composite index was the highest in ES15 - both in 2004 and 2010. The lowest composite index in 2004 was in Poland - only 39.09 and in 2010 - in Latvia - 45.7. Lithuania's index respectively reached 45 and 51 points. Social indicators, like number of doctors, children mortality, unemployed, crime rate and poverty level, mainly influenced sustainability index. Only some indicators from economic and environmental spheres had influence an overall index of sustainability.
\end{abstract}

Keywords: sustainability, assessment, composite index, EU, Lithuania.

\section{Introduction}

Sustainable development is a dynamic process and it is important to examine its progress. Objective of sustainable development assessment is selection of appropriate methods, which is possible only the simultaneous taking into account all the parameters [1], [2].

Many state policies in order to achieve specific goals do have a negative impact on the country's other strategic priorities and policies implemented and often contradict each other. Hence, state policy harmonization can help to improve the efficiency of public administration, which is problematic in Lithuania. An important issue is the impact on sustainable development or sustainability assessment, allowing the state to assess the impacts on sustainable development of the set policy [3]. This also allows to provide the integrated nature-society systems assessment (from global to local) in the longterm and in the short term, allowing determine what action to take or not to take [4].

While developing and implementing national, regional and global strategies for sustainable development and monitoring their implementation, usually various indicators' systems to reflect different aspects of sustainable development and control indicators associated with specific sustainable development targets and measures are used [1].

Indicators provide the basis for assessing progress towards the long-term development goals. An indicator is something that draws attention to a problem or condition. Its purpose is to show how well the system works. If there is a problem, the indicator can help determine what direction to take to address the issue [5]. Sole indicators have several advantages. First, the data are readily available and can be used in the comparison. Second, the traditional indicators can help identify problem areas. Third, the traditional indicators can be combined to create sustainability indicators [5], [6]. On the other hand, analysis of sole indicators sometimes might be misleading.

B. Moldan and A. L. Dahl [7] distinguished indicators, the aggregate indicators, combined (composite) indicators and indices. B. Ness et al. [8] most of sustainability assessment methodologies grouped into the four groups, stating that indicators and the indicators, which are further subdivided into not integrated and an integrated ones, consist one of these groups.

Corresponding author: Renata Dagiliūtè. E-mail address: r.dagiliute@gmf.vdu.lt

http://dx.doi.org/10.3846/enviro.2014.012

(C) 2014 The Authors. Published by VGTU Press. This is an open-access article distributed under the terms of the Creative Commons Attribution License, which permits unrestricted use, distribution, and reproduction in any medium, provided the original author and source are credited. 
Complex (composite) indices (indexes) are synthetic indices of individual groups of indicators used for comparison and ranking of countries in areas such as environmental performance and sustainable development [2]. Composite indices are valued for the ability to integrate large amounts of information in an easily understandable format. They reduce the volume conveyed statistics and allow easy comparison of countries [9], [10]. In addition, composite index eliminates problems caused by the lack of information on certain individual characteristics [11]. Possible related uncertainties could be minimized and controlled [12]. Nevertheless, indicators selection might be influenced by country peculiarities [13]. A number of various indices and composite indicators have been developed (Index of Sustainable Economic Welfare, Genuine Progress Indicator, Well-Being Index, Human Development Index, Ecological Footprint, Environmental Sustainability Index, Environmental Vulnerability Index, Living Planet Index, and Environmental Performance Index). Their application, advantages and disadvantages were discussed widely [11], [14-19 and others].

Sustainability assessment in Lithuania is mostly based on separate indicators analysis and rather few works, mainly on regional scale [21-23], are done on integrated assessment. This paper aims to evaluate the alteration of sustainable development by applying composite index for Lithuania and other EU countries during 2004-2010.

\section{Methodology}

The study used 2004-2010 data for sustainable development taken from the Eurostat database. The old EU member states (EU15), Lithuania, Latvia, Estonia, Poland and the Czech Republic were included into research. These countries were chosen because all these Central and East Europe (CEE) countries joined EU in 2004 and they share some similar past and history.

The composite index was calculated according to the OECD Handbook on constructing composite indicators methodology and user guide [24]. According to this methodology, indicators can be selected such that seem important and as many as needed. Biggest advantage is that this method is sufficiently flexible as it can be applied to any evaluation period and various cuts, choosing the best indicators reflecting the evolution of sustainability issues and the desired number of them.

To obtain a comparable index and to avoid influence of population change, indicators have been calculated per capita, per 1000 inhabitants, as a percentage of the population, or some proportion. For the composite index, the following indicators presented in Table 1 were selected and composed the sub-indices and the final composite index.

According to R. K. Singh et al. [11] for the calculation of the composite index, the standardization of $z$ or $t$ scores is used. In this study, all the indicators of each year were standardized using $\mathrm{T}$ scores obtaining values from zero to 100 applying this formula:

$$
T=50+10\left(\frac{x-\bar{x}}{s}\right),
$$

where $x$ is value of indicator of a given year, $\bar{x}-$ the mean value of a given indicator, $s-$ standard deviation of the given indicator.

Those T values, which increase indicated unsustainable trends, were recalculated to have all indicators in "one direction". All indicators were included into sub-indexes on the equal weight basis. Calculated sub-indices have been included into final composite index on equal proportions as well (Table 1). Regression analysis was applied to determine influence of sole indicators on composite index of sustainable development.

Table 1. Indicators included into analysis

\begin{tabular}{lll}
\hline Indicator & Sub-index & Composite index \\
\hline GDP, PPS/cap & & \\
Labour productivity, Euro/per hour & Economy & \\
Export, PPS/cap & & \\
Import, PPS/cap & & \\
Energy intensity, $\mathrm{kg}$ oe/1000PPS & \\
Material intensity, kg/1PPS & \\
Number of tourists, per 1000 inh. & \\
\hline Emission of $\mathrm{CO}_{2}, \mathrm{t} / \mathrm{cap}$ & \\
Emission of $\mathrm{SO}_{\mathrm{x}}, \mathrm{kg} / \mathrm{cap}$ & \\
Emission of $\mathrm{NO}_{\mathrm{x}}, \mathrm{kg} / \mathrm{cap}$ & \\
Waste, $\mathrm{kg} / \mathrm{cap}$ & Environment index \\
Final energy consumption, toe/cap & \\
Renewable energy resources in final energy consumption, $\%$ & \\
Material consumption, $\mathrm{t} / \mathrm{cap}$ & \\
Protected areas, \% of the country area & \\
\hline
\end{tabular}




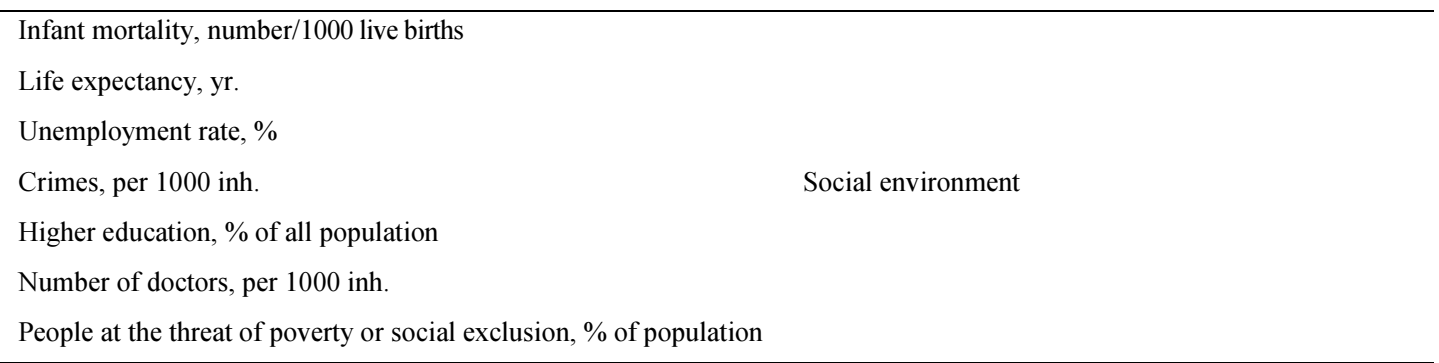

\section{Results and discussion}

\subsection{Sub-indexes and their trends}

EU-15 economic sub-index (Fig. 1) was the largest (greater than the average) and slightly increasing. All sole economic indicators were the highest in the EU15, although their change during the whole period was not so remarkable. For other countries, a sharp increase (10 points) seen since 2005. In 2004 these countries joined the EU, and this was followed by increase in GDP per capita, exports, and decreased energy and materials intensity. However, economic sub-index was much lower in New EU member states. Economic sub-index was the lowest in Latvia and Estonia, as their economic indicators were the smallest. Meanwhile, Lithuania sub-index amounted to 50 points.

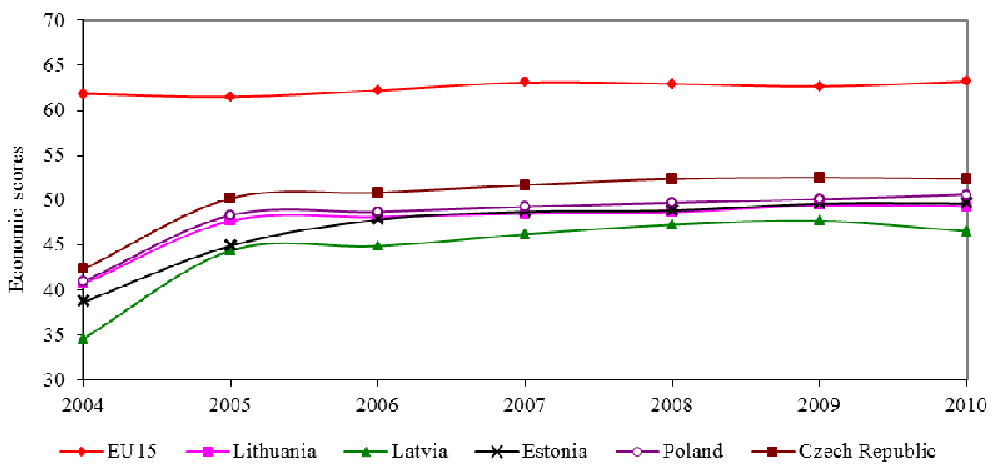

Fig. 1. Economic sub-index during 2004-2010 (own calculations)

Social sub-index (Fig. 2) shows greater fluctuations than economic indices. Social environment sub-index was the largest in the EU15 and the Czech Republic (about 53-55 points), because most of indicators were higher to compare to those of the other countries. Social indicators in EU15 were the best, excluding large number of crimes. Social indicators in the Czech Republic were also good and they have improved: infant mortality, poverty and unemployment decreased. Slightly smaller social sub-index was estimated in Estonia and Lithuania (50-53 points). Lower than the average social sustainability was in Latvia and Poland. Small number of doctors, high infant mortality, high unemployment and high level of poverty influenced this. In Lithuania and Latvia in 2009, the social sub-indices decreased as the unemployment has increased significantly.

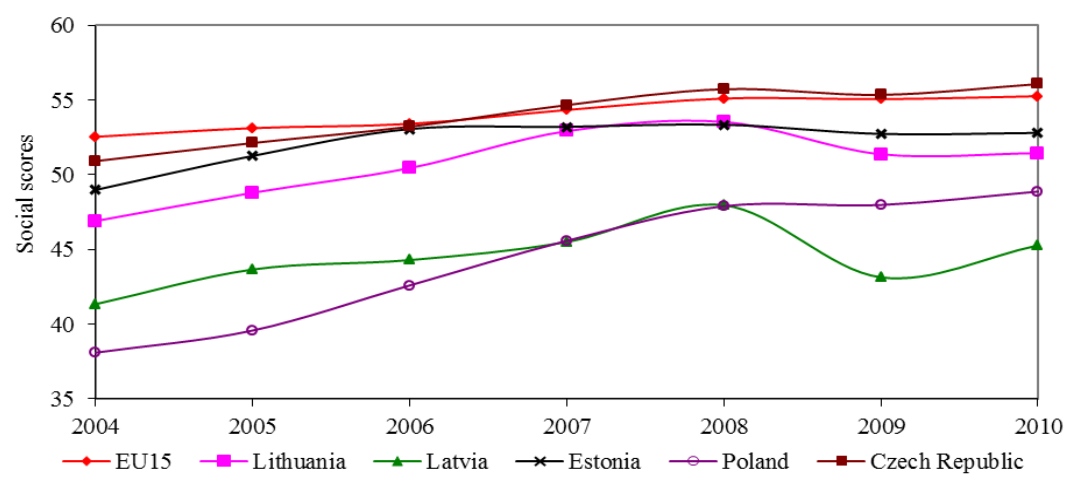

Fig. 2. Social sub-index during 2004-2010 (own calculations)

Environmental sub-index (Fig. 3) ranges in all countries except the EU15. That is, until 2006-2007 environmental subindexes were on decreasing trends and then began to increase. This could be influenced by rapid economic growth at the expense of environment during pre-crisis period. It also shows that the environmental sub-indices are higher than the economic and social ones. The highest environmental sub-index is registered in Latvia and Lithuania. Low air pollution, low 
use of resources and relatively high share of RES in final energy consumption (in Latvia was the largest) and protected areas in the country influenced relatively good situation in these countries.

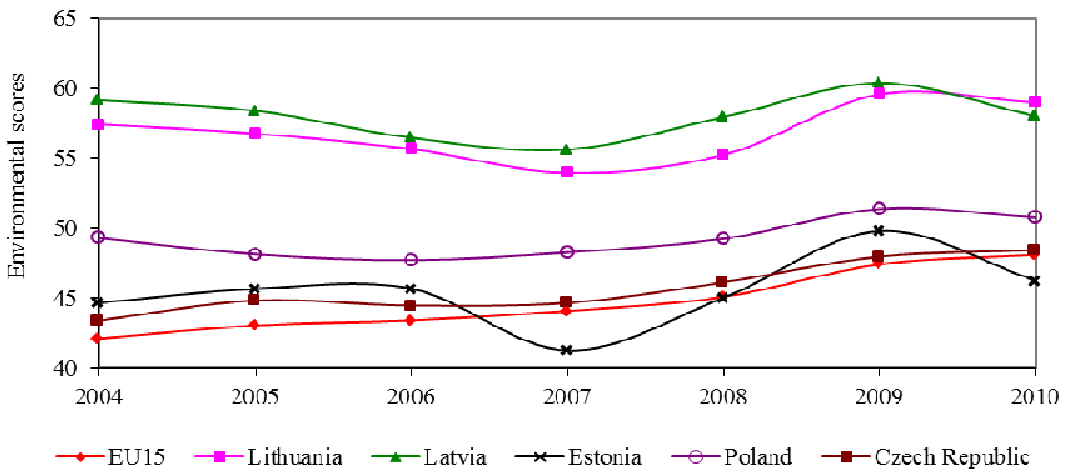

Fig. 3. Environmental sub-index during 2004-2010 (own calculations)

\subsection{Composite sustainability index and its changes}

Composite sustainability index (Fig. 4) clearly shows that the changes are the lowest in the EU15 countries. Nevertheless, during the period the composite sustainability index increased by $4 \%$ because the social and the environmental sub-indices gradually improved in EU15. Development in new EU member states was more remarkable $(2004=100 \%)$ and differed from the EU15 countries around 10-20\%. The biggest change was in Poland (27\%), largely due to improved social indicators compared with 2004. In other countries, the composite index increased about $15 \%$. Though change of composite sustainability index was the smallest, overall index was the largest in the EU15, both in 2004 and 2010, respectively reaching 55.6 and 57.9 points (Fig. 5). Lowest sustainability index in 2004 was in Poland (39.05) and Latvia (39.09), the lowest for the year 2010 - in Latvia - 45.7 points. Despite that, during the reference period the difference between Latvia and the EU-15 decreased from 16.5 to 12.2 points. Meanwhile, Lithuanian and Estonian sustainability indices both in 2004 and in 2010 were very similar and amounted to 45 and 51 points respectively. Czech composite sustainability index is the closest to the EU-15 index, reaching 48 and 55 points.

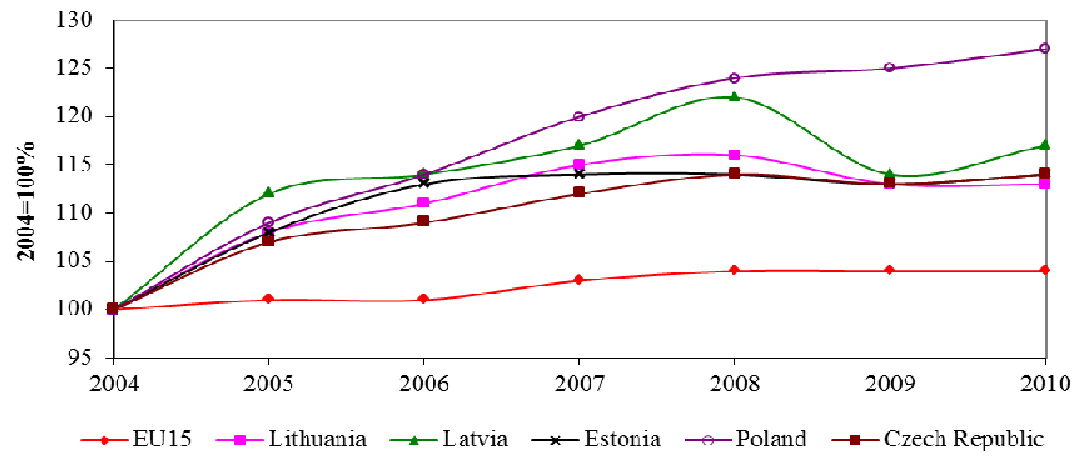

Fig. 4. Composite index changes during 2004-2010 (2004=100\%) (own calculations)

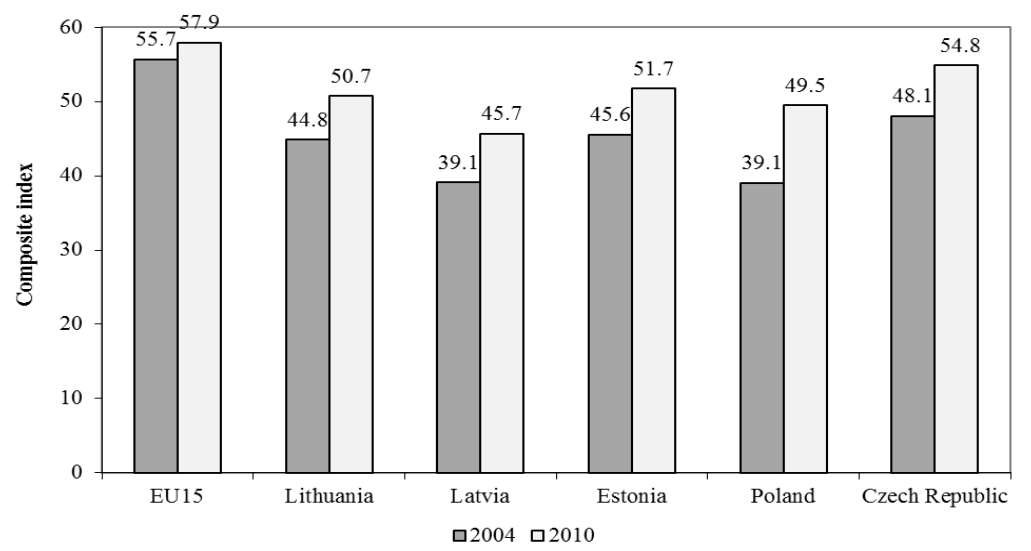

Fig. 5. Composite index in 2004 and 2010 (own calculations) 
Table 2. Regression results for factors influencing composite index for all countries $(\mathrm{R} 2=0.99)$

\begin{tabular}{lll}
\hline Factors & $\mathrm{B}$ & $\mathrm{p}$ \\
\hline Intercept & 64.32 & 0.00 \\
Export & 0.001 & 0.00 \\
Import & -0.001 & 0.00 \\
Material intensity & -1.919 & 0.00 \\
Number of tourist & 0.002 & 0.00 \\
Number of doctors & 1.727 & 0.00 \\
Infant mortality & -0.494 & 0.00 \\
Unemployment rate & -0.053 & 0.00 \\
Crimes & -0.086 & 0.00 \\
People at the threat of poverty or social exclusion & -0.1 & 0.00 \\
Waste & -0.002 & 0.036 \\
Emission of $\mathrm{SO}_{x}$ & -0.022 & 0.00 \\
Emission of $\mathrm{NO}_{x}$ & -0.212 & 0.00 \\
Protected areas & 0.214 & 0.00 \\
Material consumption & -0.101 & 0.00 \\
\hline
\end{tabular}

In general the composite index was influenced by the export, import, material intensity, number of tourists, number of doctors, infant mortality, unemployment rate, crime number, poverty, waste generation, SOx, NOx, material consumption, protected areas (Table 2). Most influential is the material intensity $(B=-1.919, p<0.05)$, number of doctors $(B=1.727$, $\mathrm{p}<0.05)$ and infant mortality $(\mathrm{B}=-0.494, \mathrm{p}<0.05)$.

\section{Conclusions}

The biggest economic sub-index was in the EU15 (62 points). In these countries, most of the economic indicators were relatively high, although the change during the period was negligible. Changes in new EU member states were larger. During the analysed period their GDP and exports increased by $50-140 \%$, energy and materials intensity decreased by half. However, the economic sub-index in these countries reached only $45-52$ points.

Social environment sub-index also was the highest in the EU15 and in the Czech Republic - 54 points. This was result of good social indicators, especially in the Czech Republic, where one-third decrease in infant mortality, poverty and unemployment is registered. Slightly smaller sub-index was in Lithuania and Estonia (51 points), while poverty decreased by $20 \%$ and infant mortality rate - almost $50 \%$. The lowest social sub index was Latvia and Poland -43 points.

The highest environmental sub-index was in Latvia and Lithuania (57 points) due to the relatively low air pollution, lower resource consumption, and wider use of the RES. Lowest environmental sub-index was that of the EU15, the Czech Republic and Estonia - about 45 points. In EU15 environmental indicators have improved, but not significantly. Meanwhile, in Estonia burning of shale resulted in high $\mathrm{CO}_{2}, \mathrm{SO}_{\mathrm{x}}$, and $\mathrm{NO}_{\mathrm{x}}$ pollution.

Composite sustainability index changes are the lowest in the EU15, as these countries are already stable and the economy is growing slowly. Changes in the new EU members were significantly higher $(2004=100 \%)$ and differed from the EU15 by $10-20 \%$. Though change of EU15 composite sustainability index was the smallest, it was the highest both in 2004 and in 2010, respectively 55.6 and 57.9 points. In 2004 sustainability index was the lowest in Poland (39.05) and in 2010 - in Latvia (45.7). Meanwhile, in Lithuania and Estonia, the sustainability index in 2004 and 2010 was very similar, 45 and 51 points respectively. During the reference period, the difference between Lithuania and the EU-15 decreased by 3.64 points.

The overall composite index of all countries was mostly influenced by the material intensity $(B=-1.919, p<0.05)$, number of doctors $(B=1.727, p<0.05)$ and infant mortality $(B=-0.494, p<0.05)$.

\section{References}

[1] Čiegis, R.; Tamošiūnas, T.; Ramanauskienè, J.; Navickas, K. 2010. Darnaus industriniu zonu vystymosi vertinimas. Šiauliai: Šiaulių universiteto leidykla.

[2] Čiegis, R.; Ramanauskienè J. 2011. Integrated assessment of sustainable development: Lithuanian case [in Lithuanian], Management theory and studies for rural business and infrastructure development 2(26): 39-49.

[3] Štreimikienè, D.; Mikalauskienè, A. 2009. Integruotu rodiklių taikymas Nacionalinės energetikos strategijos monitoringui, Energetika 3(55): 158-166.

[4] Šaparauskas, J. 2004. Darnaus miesto vystymo(si) daugiatiksle selektonovacija. Daktaro disertacija. Vilnius: Vilniaus Gedimino technikos universitetas. p. 143

[5] Žičkienė, S. 2004. Sustainable Development of Lithuania: Tentative Evaluation, Environmental research, engineering and management 1(27): 15-20.

[6] Atkinson, G. D.; Dubourg, R.; Hamilton, K.; Munasignhe, M.; Pearce, D.W.;Young, C. 1997. Measuring Sustainable Development. Macroeconomics and the Environment. Edward Elgar, Cheltenham. 
[7] Moldan, B.; Dahl A. L. 2007. Measuring progress towards sustainability: assessment of indicators. A Project of SCOPE, the Scientific Committee on Problems of the Environment, of the International Council for Science. Washington, DC. p. 1-26.

[8] Ness, B.; Urbel-Piirsalu, E.; Anderberg, S.; Olsson L. 2007. Categorising tools for sustainability assessment, Ecological Economics 60(3): 498-508 http://dx.doi.org/10.1016/j.ecolecon.2006.07.023

[9] OECD. 2002. Indicators to measure decoupling of environmental pressures from economic growth. Paris.

[10] OECD. 2005. Measuring Sustainable Development. OECD Statistics Brief. September. No. 10.

[11] Singh, R. K.; Murty H. R.; Gupta S. K.; Dikshit A.K. 2009. Review: An overview of sustainability assessment methodologies, Ecological Indicators 9: 189-212. http://dx.doi.org/10.1016/j.ecolind.2008.05.011

[12]Floridi, M.; Pagni, S.; Falorni, S.; Luzzati, T. 2011. An exercise in composite indicators construction: Assessing the sustainability of Italian regions, Ecological Economics 70: 1440-1447. http://dx.doi.org/10.1016/j.ecolecon.2011.03.003

[13] Böhringer, Ch.; Jochem, P. E. P. 2007. Measuring the immeasurable - A survey of sustainability indices, Ecological Economics 63(1): 1-8. http://dx.doi.org/10.1016/j.ecolecon.2007.03.008

[14] Moffatt, I. 2000. Ecological footprints and sustainable development, Ecological Economics 32: 359-362.

[15] Prescott-Allen, R. 2001. The Well-Being of Nations: A Country-by-Country Index of Quality of Life and the Environment. Island Press, Washington, DC.

[16] Stöglehner, G. 2003. Ecological footprint - a tool for assessing sustainable energy supplies, Journal of Cleaner Production 11: $267-277$. http://dx.doi.org/10.1016/S0959-6526(02)00046-X

[17] Pope, J. 2004. Conceptualizing sustainability assessment. Environmental Impact Assessment 24: 595-616. http://dx.doi.org/10.1016/j.eiar.2004.03.001

[18] Wilson, J.; Tyedmers P.; Pelot P. 2007. Contrasting and comparing sustainable development indicator metrics, Ecological Indicators 7: 299-314. http://dx.doi.org/10.1016/j.ecolind.2006.02.009

[19] Siche, J. R.; Agostinho, F.; Ortega, E.; Romeiro, A. 2008. Sustainability of nations by indices: Comparative study between environmental sustainability index, ecological footprint and the energy performance indices, Ecological Economics 66: 628-637. http://dx.doi.org/10.1016/j.ecolecon.2007.10.023

[20] Esty, D. C.; Daniel, C.; Levy, M. A.; Kim, C.; de Sherbinin A.; Srebotnjak, T.; Mara, V. 2008. Environmental performance index. New Haven: Yale Centre for Environmental Law and Policy.

[21] Ginevičius, R.; Podvezko, V. 2009. Evaluating the changes in economic and social development of Lithuanian counties by multiple criteria methods, Technological and Economic Development of Economy 15(3): 418-436. http://dx.doi.org/10.3846/1392-8619.2009.15.418-436

[22] Brauers, W. K. M.; Ginevičius, R.; Podvezko, V. 2010. Regional development in Lithuania considering multiple objectives by the MOORA method, Technological and Economic Development of Economy 16(4): 613-640. http://dx.doi.org/10.3846/tede.2010.38

[23] Dagiliūtè, R. 2012. Sustainability of Lithuanian regions application of composite index. Regional formation and development studies: journal of social sciences 3(8): 65-73.

[24] OECD. 2008. Handbook on Constructing Composite Indicators: methodology and user guide. p. 158. 